\title{
A Comparison of Noxious Facilities' Impacts for Home Owners versus Renters
}

\author{
David. E. Clark \\ Department of Economics \\ Marquette University \\ Milwaukee, WI 53233 \\ and \\ Argonne National Laboratories \\ Argonne, IL 60439
}

and

Leslie. A. Nieves

Argonne National Laboratories

9700 South Cass Avenue

Argonne, IL 60439

Abbreviated title: Noxious Facilities' Impacts Comparison

Address correspondence to L.A. Nieves

\section{DISCLAIMER}

This report was prepared as an account of work sponsored by an agency of the United States Government. Neither the United States Government nor any agency thereof, nor any of their employces, makes any warranty, express or implied, or assumes any legal liability or responsibility for the accuracy, completeness, or usefulness of any information, apparatus, product, or process disclosed, or represents that its use would not infringe privately owned rights. Reference hercin to any specific commercial product, process, or service by trade name, trademark, manufacturer, or otherwise does not necessarily constitute or imply its endorsement, recommendation, or favoring by the United States Government or any agency thereof. The views and opinions of authors expressed herein do not necessarily state or reflect those of the United States Government or any agency thereof.

The submiesed manuscriot has been authored The submitzed manuserot of the U.S. Government by a contractor of the W-31.109ENG-38. under contract $U$. Government retains a Accordingly. the U. S. Government to publish nonexclusive, royally published form of this or reproduce the published to do so. for U. G. Government purposes. 


\section{DISCLAIMER}

Portions of this document may be illegible in electronic image products. Images are produced from the best available original document. 


\section{Abstract \\ A Comparison of Noxious Facilities' Impacts \\ for Home Owners versus Renters}

The siting of noxious facilities, such as hazardous waste facilities, is often vigorously opposed by local residents, and thus it is now common for local residents to be compensated for the presence of the facility. One technique that has been employed to implicitly value noxious facilities is the intercity hedonic approach, which examines the wage and land rent premia between cities that result from the presence of the facility. However, most of the focus has been on the behavior of home owners as opposed to renters. Since these two groups of residents vary on numerous dimensions such as marital status, age, sex, and personal mobility, it would not be surprising to find different marginal valuations of local site characteristics.

We use 1980 Census data to derive separate estimates for owners and renters of the implicit value placed on eight different types of noxious facilities. We find that renters and owners differ in their response to noxious facilities, although the differences are not systematic. Furthermore, the differences between owners and renters are not primarily due to differential mobility or sociodemographic factors. Controlling those factors decreases the differences between renters' and owners' implicit valuations of noxious facilities by less than $10 \%$. Unmeasured differences between the two groups, such as tastes, risk aversion, or commitment to the community, must account for the remaining difference in valuations. These findings suggest that policymakers should should separately consider the responses of owners and renters when estimating noxious facility impacts.

Key words: noxious facilities, housing tenure, implicit prices, impact valuation 


\section{A Comparison of Noxious Facilities' Impact \\ for Home Owners versus Renters}

\section{INTRODUCTION}

Attempts to site noxious facilities frequently face intense opposition from local residents. Over the past two decades, economists have applied several alternative techniques to estimate public willingness to pay to avoid proximity to such facilities. One of the more successful techniques is the hedonic approach, which identifies the portion of any property value and/or wage differentials associated with a variety of local characteristics. This approach has been employed in several studies to estimate the impact that existing facilities have on local residents. ${ }^{(1.2 .3)}$ Of the studies focusing on the housing market, most examine the impacts on homeowners. However, one hedonic study by Linneman ${ }^{(4)}$ examines the differences in impact estimates for separate samples of owner-occupants and renters. While Linneman does not examine noxious facilities specifically, he does find that both the signs and significance levels of various location-specific characteristics vary by housing tenure category (i.e. owners vs. renters). Moreover, we believe that there are compelling theoretical reasons for differing responses of these two groups.

First, due to differences in their demographic characteristics, the two groups may have different aversions to the hazards associated with the facilities. For example, attitudes toward environmental risks have been found to be associated with individual characteristics such as education, income, sex, and age. Studies of risk perceptions of complex technology or environmental threats that have used U.S. population samples have generally found a greater intensity of risk perception among females than males. Analyzing attitudes of males and females separately, Mitchell( ${ }^{()}$found that having children under the age of 18 increased risk perception for women but not for men. Findings related to other demographic characteristics have not been totally consistent across surveys, but, overall, the intensity of risk perception tends to be lower among older and among more highly educated segments of the population. 
Second, there appear to be differences between owners and renters in levels of concern for environmental hazards, though previous studies have not controlled for demographic characteristics. An interesting study by $\mathrm{Cutter}^{\left({ }^{(}\right)}$explores the relationship between concern with environmental pollution, demographic characteristics, and measures of the occurrence of hazards in each Census tract. She finds that concern increases significantly with the rate of hazard occurrence in the local community and that renters, African-Americans, and lower income groups have higher levels of concern. A more recent study by Howe ${ }^{(0.8)}$ examines relationships between four different indices of environmental concern and detailed demographic variables. While regional differences in responses were evident, women and persons with children under 18 were generally more concerned with environmental and health risks. Higher levels of concern were also found among those who were younger and had less education and among renters. These findings suggest that differences in measured responses to environmental hazards may result from unmeasured factors related to housing tenure status.

A third factor which may generate differences in rates at which local amenities are capitalized into property values and wages for homeowners or for renters is the differential mobility of the two groups. If the transactions costs associated with moving are higher for owners, then relatively lower mobility for owner-occupants, as compared to renters, can result in different marginal valuations on noxious facilities. For example, highly mobile individuals may be more responsive to slight interregional variations in amenities than their less mobile counterparts. This suggests that small impacts may not be detectable if moving costs are high. In fact, Boehm ${ }^{(\mathfrak{)})}$ and more recently, Boehm, Herzog and Schlottmann ${ }^{(10)}$ have shown that mobility, both within and between metropolitan areas, and tenure choice are interrelated. Households that anticipate a move are less likely to choose to be owner occupants.

In this study, we employ an interregional framework in an hedonic analysis of both wage and property markets to examine the hedonic impacts of eight different noxious facility types. Annual wage and housing expenditure equations are estimated separately for owners and renters to derive separate 
implicit price estimates for the two groups. Our findings suggest differences in implicit prices for owners and renters. Furthermore, these differences do not just reflect dissimilarity in the mobility or demographic characteristics of the two groups, since the divergence of implicit prices between owners and renters decreases by only a small margin when mobility and demographics are controlled. Finally, although differences have been identified, no consistent patterns emerge.

\section{OVERVIEW OF HEDONIC MODEL}

Although there are numerous examples of hedonic studies which examine the intracity variation in either property values or rents resulting from noxious facilities, ${ }^{1}$ noxious facility impacts can also be derived using an intercity hedonic framework. ${ }^{2}$ The intercity model examines the joint impact of sitespecific characteristics on both local wages and land rents. Roback ${ }^{(1)}$ and later Blomquist, Berger and Hoehn ${ }^{(2)}$ show that implicit prices can be derived from the wage differential and land rent premium associated with improvements in site-specific characteristics. Furthermore, the intercity model may offer some distinct advantages over the intracity model. For example, Cropper and Arriaga-Salinas ${ }^{(1)}$ point out that, unlike the intracity hedonic model, which only considers changes in residential property values, the intercity model values site characteristics at the place of work as well. In addition, Clark and Nieves (ึ) argue that site characteristics that have broad regional economic effects may have relatively flat local impact gradients. Thus, intercity differentials in such site impacts may be more substantial than intracity effects. Furthermore, intercity hedonic models allow a wide range of facility types to be investigated simultaneously, facilitating a comparison of relative impacts. For those facility types exhibiting variation between and within cities, both models can used and the findings can be compared for consistency.

The intercity hedonic model has been fully developed elsewhere, ${ }^{(2.11 .13 .14)}$ so we present an abbreviated version of the model here. ${ }^{3}$ The intercity hedonic model is a general equilibrium model, 
which assumes perfect information, zero moving costs and, hence, perfect mobility on the part of both utility-maximizing households and cost-minimizing firms. Since the focus of this model is on intercity variation, characteristics are assumed to be uniform within cities. Households maximize utility, which is derived from the consumption of a composite good (X), land (D), and location-specific amenities and disamenities (A). This maximization is subject to the available budget, determined by the wage, W. The price of land is $R$, and the composite good price is assigned a value equal to unity.

$$
\begin{aligned}
& \operatorname{Max} U=U(X, D ; A) \\
& \text { subject to } W=X+R * D
\end{aligned}
$$

Spatial equilibrium for households requires constant utility across space, and the indirect utility function defines that constant utility level, $\mathrm{V}^{*}$, as a function of the composite good price, wages, land prices, and the amenity offerings across locations. The intercity model derives the indirect utility function by substituting the optimizing levels of land, $\mathrm{D}^{*}$ and the composite good, $\mathrm{X}^{*}$, into the utility function.

$$
\mathrm{V}^{*}=\mathrm{V}(1, \mathrm{~W}, \mathrm{R} ; \mathrm{A})
$$

Spatial equilibrium for households is described in Figure 1 by a constant utility surface $(V)$ in wage/rent space. For the sake of illustration, consider the effect of an increase in a disamenity level, such as in air pollution, which results in higher costs for firms as a result of more stringent regulation in regions with lower air quality. An increase in air pollution in a particular location will shift the constant utility surface down and to the right $\left(V_{1}\right.$ to $\left.V_{2}\right)$ since the price residents will be willing to pay for land will decrease, and at the same time, they will require higher wages to compensate for increases in the disamenity. 


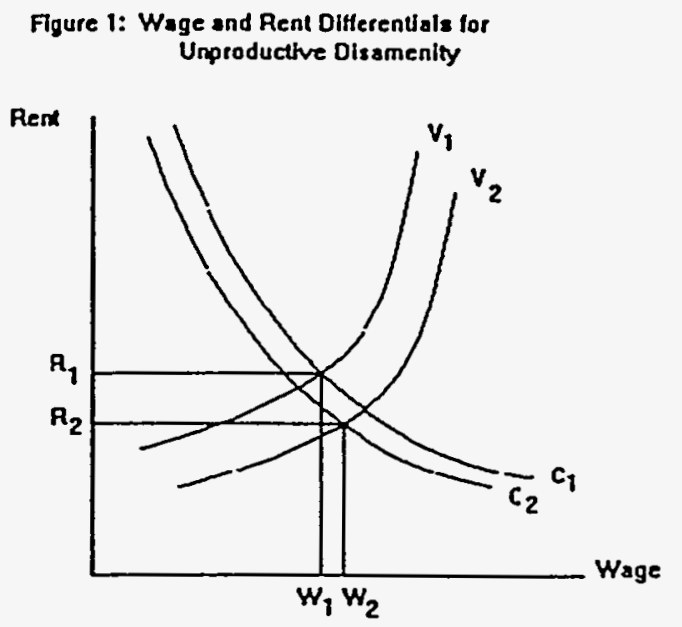

Firms are also assumed to minimize the cost of production subject to the available technology. We assume that firms operate in competitive input and output markets, and that production takes place under constant returns to scale technology.

$$
\begin{aligned}
& \text { Minimize } C=(W, L, D, R ; A) \\
& \text { subject to } X=X(L, D ; A)
\end{aligned}
$$

Solving the equation system (4)-(5) for optimal values of labor (L) and land (D), and substituting those values back into the cost function (4), yields the unit cost function. When firms are in spatial equilibrium, wages and land rents adjust so as to maintain costs at some constant level (set equal to the price of good $\mathrm{X}$ in the competitive output market). Thus, given some disamenity level, there exists a tradeoff between $\mathrm{W}$ and $\mathrm{R}$ which maintains unit costs (i.e., $\mathrm{C}_{1}$ in Figure 1).

$$
1=\mathrm{C}(\mathrm{W}, \mathrm{R} ; \mathrm{A})
$$

If increases in the the disamenity increase production cost, then the unit cost function shifts inward $\left(C_{1}\right.$ to $C_{2}$ in Figure 1), as firms are able to pay less for labor and land while maintaining the unit cost level. Simultaneously solving equations (3) and (6) for $\mathrm{W}$ and $\mathrm{R}$ is shown graphically by the 
intersection between the indirect utility function $\left(V_{1}\right)$ and the unit cost function $\left(C_{1}\right)$. When the disamenity level rises, this moves the equilibrium location from point $\left(R_{1}, W_{1}\right)$ to $\left(R_{2}, W_{2}\right)$. In this example, the increase in the disamenity unambiguously reduces the equilibrium rent level, but has an uncertain effect on the wage.

Roback $^{(11)}$ and Blomquist, Berger and Hoehn ${ }^{(\mathcal{A})}$ derive the implicit price for the disamenity (P) as the weighted sum of the joint impact of the amenity on wages and rents:

$$
P^{*}=W^{*} k_{1}^{*} d \ln R / d A-W * d \ln W / d A
$$

The fraction of income spent on land is represented by $k_{l}$, so the expenditure on land $\left(W^{*} k_{1}\right)$ provides the weight on the land-rent component of the implicit price. The following section derives reduced-form wage and land-rent functions for both owners and renters. These functions are then used to derive implicit price estimates for various location-specific attributes, and the findings are compared for the two groups.

\section{AN EMPIRICAL MODEL OF NOXIOUS FACILITY IMPACTS}

\subsection{Data}

A data base is developed that combines individual data on housing values and wages with various regional attributes. Individual data are defined separately for home owners and renters. To implicitly value noxious facilities, a unique data set is constructed for eight different facility types. The selection of study sites was a multistage process starting with the choice of a range of facility types that present different physical hazard risks to the surrounding population. The facility categories include three different types of power generating plants: nuclear, coal-fired, and gas- and oil-fired. We also include military chemical weapons storage facilities slated for decommissioning, hazardous waste sites, ${ }^{6}$ petrochemical refineries, and liquefied natural gas storage facilities. The final category of noxious facility 
is radioaction-contaminated sites managed by the U.S. Department of Energy. For the spatial units examined in this sample, coverage of the various facility types is complete.

Geographic areas are selected from the PUMS ${ }^{(1)}$ data and are spatially defined using county groupings. An important advantage of using the PUMS is that it permits the creation of a sample that is spatially representative, covering a full range of site characteristics. Since the PUMS county groupings may cover a wide geographic area, a second goal of the sample selection is to choose sites that constitute a geographic area small enough so that average amenity levels within that area are representative for the resident population. In a few cases where a region and facility type could be represented by two alternative county groupings of significantly differing $\mathrm{mi}^{2}$, the smaller county grouping was chosen. Finally, PUMS county groupings composed of noncontiguous geographical areas, or regions covering more than $10,000 \mathrm{mi}^{2}$ were dropped from the analysis. Thus, study areas in the final sample range from 22 to $7,218 \mathrm{mi}^{2}$, with a mean area of approximately $1,500 \mathrm{mi}^{2}$. The resulting sample consists of 76 PUMS study areas, of which 70 contain 262 noxious facility sites. The density of many of these types of facilities generally increases with population density. The distribution of the study facilities among the nine Census Divisions is shown in Table I. The Middle Atlantic region contains the largest number of facilities (78), due primarily to the number of hazardous waste sites identified in these states. The distribution of most facility types appears to reflect the distribution of the total population of facilities among regions.

\subsection{Model Overview}

Reduced-form wage and property value or rental expenditure equations are given by equations (8) and (9) below.

\footnotetext{
ANNWAGE $=$ W(HC\&IND, PRICE, DISEQ, AMENITY, FISCAL, NOXIOUS)

VALUE or RENT $=$ F(STRUCT, PRICE, DISEQ, AMENITY, FISCAL, NOXIOUS) $(9)$ 
Independent variables for human capital and industry controls (HC\&IND) are included in the wage equation, whereas housing structural characteristics (STRUCT) are included in the housing value equation. Additional vectors of independent variables include local prices (PRICE), disequilibrium controls (DISEQ), amenities and disamenities (AMENITY), tax and expenditure levels in the region (FISCAL), and noxious facilities (NOXIOUS).

Data from several sources were assembled to construct a data set that covers wage and property markets, the local amenities and fiscal mix, and the socio-economic structure. All of the data are for 1979-80. Data for wages, residential property values, and the range of associated individual attributes needed for a hedonic analysis are taken from the PUMS.

The samples of home owners and of renters used to estimate the wage equations are composed of those 18 years and older who report wage and salary income or nonfarm self-employment income. The sample is confined to workers who earn calculated wages in excess of $\$ 2.00$ per hour, who both live and work in one of the study sites, and for whom occupation is identified. Because the PUMS income data distribution is truncated, the income category of " $\$ 75,000$ and up" is omitted from the analysis. The final sample size is 23,735 persons for the home owners' sample and 6,838 for the renters' sample.

The housing samples include owner- or renter-occupied units and exclude units lacking individual access and residences used for commercial purposes. Owner units with reported property values in the category "\$175,000 and up" are excluded, as are rental units with rent and utilities of "\$999 and up." The resulting owners' sample consists of 45,899 units and the renters' sample has 11,999 units.

The remaining data are taken from numerous sources, as noted in Table II, and are typically defined for a city or county in the region. In all cases, the county and city data that most closely correspond geographically to the PUMS data unit for each study site are selected. 


\subsubsection{Wage Models}

Annual wages are defined as the summation of annual wages and self-employment income (ANNWAGE). The vector of human capital and industry characteristics (HC\&IND) included are listed in Table II. In addition, two sets of dummy variables represent the occupation and industry of the worker. The latter category is included to control for differences in occupational risk across industries.

A comparision of the human capital as well as other characteristics of the renter and owner samples is presented in Table III. While education levels are similar, renters are approximately 4.5 years younger than owners. In addition, renters are more likely to be nonmarried, and slightly less likely to be white or to be a military veteran. Concerning geographic location, renters are more likely to reside in central city locations, and less likely to live in rural counties than are owners. Finally, there is a marked difference in observed mobility of the two groups. On average, renters have moved within the last 4 years, whereas the average number of years since the last move is almost 14 years for home owners.

\subsubsection{Housing Value and Rent Expenditure Models}

The annualized land value component of housing value (ANNVALUE) is derived from the owner's estimate of the market value of the residence and, in the case of renters, is derived from annual rent (ANNRENT), which is gross rent including utilities. The variable YRMOVED, which is the time period since moving into the house, is used to capture the mobility of the individual. However, it should be noted that it may also serve as a proxy for accuracy in the valuation of the residence, since it can be expected that those who have purchased most recently will provide the most accurate value estimates. Structural characteristics (STRUCT) of the housing unit are controlled using several measures which are listed in Table II. Condominium status is controlled using a dummy variable (CONDO) in the owners' model. In the renters' model, CONDO is omitted and three other variables are included. These are a 
dummy for multi-unit building type (LOWRISE), a dummy for the presence of an elevator (ELEVATOR), and the number of separate units at a given address (UNITS).

Equations (8) and (9) share many of the same variables. Before discussing the differences, the common variables are briefly reviewed. The PRICE category contains a cost-of-living index (COLINDEX) computed without the cost of housing to account for the relative cost of produced goods. The DISEQ category is included to control for the possibility of temporary disequilibrium conditions. This category includes the unemployment rate (UNEMPLOY) and regional dummy variables representing the nine Census Divisions. In the wage model, it includes the percentage of the labor force that is unionized (PCTUNION), and, in the housing model, it includes the percentage of year-round housing units that are unoccupied (VACANCY). Percentage unionized is included in the disequilibrium category in recognition of the role of unions in maintaining higher returns to human capital than would be found under equilibrium conditions.

Amenities (AMENITY) are related to safety, climatic, environmental, and recreational conditions in the region. Several measures are used to control for climatic variation, including the average annual percent of available sunlight (PCTSUN), the average annual inches of precipitation (PRECIP), the average wind speed (AVGWIND), the difference between the average mean daily July and January temperature (TEMPDIFF), the average total cooling-degree-days (COOLDAYS), and total heating-degree-days (HEATDAYS). The variable for total suspended particulates (TSP) approximates air quality in the region since it is strongly implicated in major health effects and diminished visibility, and is moderately correlated with sulfate levels. A dummy variable representing coastal areas (COAST) approximates recreational amenities. Amenities and disamenities associated with urban scale are proxied by population density (POPDENS) and, in the housing model, by dummy variables defining the metropolitan status of the county (CNTRLCTY, RURAL) as well. Location in a Standard Metropolitan Statistical Area (SMSA) but outside of the central city is the reference case. Access to employment is 
proxied by mean travel time (MEANTRAV) for each study site. The effects of industrial concentration (e.g., congestion, pollution) are controlled by the percent of total employment comprised by manufacturing workers (PCTMFG) and the violent crime rate (VCRIME) represents the public safety amenity.

A group of tax- and expenditure-related variables are included to control for differences in fiscal conditions. Local governmental expenditures $(\$ 1000)$ per capita (LOCEXPPC) is the sum of outlays for health, welfare, police services, and education. As such, it may proxy the level of local government services. Local tax revenues $(\$ 1000)$ per capita (LOCTAXPC) which are drawn from property taxes and miscellaneous other sources are included to reflect the local tax burden. Intergovernmental transfers (\$1000) per capita (NTRGOVPC) indicate the degree to which local expenditures are supported by nonlocal sources. Finally, the marginal state tax rate for the median income category in 1980 (MGSTATAX) is included to reflect interstate differences in tax burden.

Noxious facilities are modeled in terms of the density per $1000 \mathrm{mi}^{2}$ of each type of facility in each PUMS data unit. Density is used to standardize the facility impact measure because of the large range of areas covered by the PUMS units. Included facilities were either in operation or, in the case of a few large coal (COAL) and nuclear (NUCLEAR) plants, in the final stages of construction by 1980 . Gasand oil-fired (GASOIL) plants are treated as a single category because in many cases both fuels are used at the same plant location. The radioactive industrial sites (RADCON) have residual contamination from materials produced for the Manhattan Project or subsequent projects and are not associated with any ongoing operations. All of the chemical hazardous waste sites (HAZWASTE) are presently listed on the National Priorities List of uncontrolled hazardous waste sites known as Superfund, that was established by the Comprehensive Environmental Response, Compensation and Liability Act of 1980 . While they existed in 1980 , public information about them may have been limited since they were not yet identified as Superfund sites. Two commercial radioactive waste disposal sites are also grouped in the 
HAZWASTE category. The liquefied natural gas (LNG) facilities include both storage and terminal installations. Petroleum refineries (REFINERY) and chemical weapons storage sites (CHEMDMIL) are the remaining facility categories.

\section{EMIPIRICAL FINDINGS}

\subsection{Estimated Hedonic Model Coefficients}

Before discussing the estimated implicit prices, we briefly examine the regression coefficients for both owners and renters, presented in Table IV.

\subsubsection{Human Capital and Structural Characteristics}

Coefficients on variables measuring human capital characteristics for owners and renters are typically of the expected sign and significant. Moreover, a comparison of the owner and renter models reveals that coefficients are highly similar. In no case were the estimated coefficients of opposite sign and statistically significant for both models. The only large difference was for the variable measuring marital status, where the income premium for married workers who owned their homes was nearly four times that of renters.

The findings on housing structural characteristics are also typically as expected, and frequently statistically significant. However, the similarities are not as striking as they are for the human capital variables. This is not surprising, since quality differences are likely to exist when comparing owneroccupied and rental properties. In most cases where coefficients are statistically significant in both equations, the owner premium exceeds that of renters.

\subsubsection{Price, Disequilibrium, and Location Dummy Variables}

Few of the price or disequilibrium variables have significant coefficients in the income models. The only two of these variables that are significant in the renters' income model are also significant and have the same sign in the owners' income model. PCTUNION is associated with increased wages in both 
cases, while the opposite is true of location in the middle Atlantic states. Two additional variables, COLINDEX and RURAL location, are significant in the owner's wage model but are nonsignificant and have the opposite sign in the renters' model. It is in the owners' housing model that most (all but two) variables in this category attain significance. Of the five that are significant in the renters' model, UNEMPLOY, COLINDEX, and West South Central location have the same sign as their significant counterpart in the owners' model. Only one variable, Pacific location, is significant in both models though with opposite signs.

\subsubsection{Fiscal and Amenity Variables}

Similar to the findings on price and disequilibrium variables, most of the significant coefficients on fiscal and amenity variables occur in the housing models. However, in the income equations, the annual income of owners is higher for locations where LOCEXPPC, VCRIME, and TSP are high, and where PRECIP is low. Only PCTMANUF and TSP have significant influences on renters' income, both increasing annual income levels.

In the housing models, most of the fiscal characteristics are statistically significant although signs sometimes differ for owners and renters. Increases in local taxes per capita decrease owners' housing expenditures while they increase renters'. Likewise, per capita local government expenditures increase annual expenditures for home owners, but decrease annual rental expenditures. Only the measure of intergovernmental transfers per capita has a consistent, negative effect across models.

The amenity variables are more frequently significant in the owners' equation. Annual expenditures on housing by owner occupants are significantly increased by increases in HEATDAYS, COOLDAYS, AVGWIND, PCTSUN, and POPDENS. Owners' annual expenditures are significantly diminished by increases in PRECIP, TEMPDIFF, COMMUTE, VCRIME, PCTMANUF, and TSP. For renters, higher average commuting times (COMMUTE) increase annual rents, while increases in PRECIP, COOLDAYS, and TSP decrease annual rents. 


\subsubsection{Noxious Facility Variables}

Though only the NUCLEAR power plant and REFINERY variables have significant coefficients in both the owners' and renters' income models, all of the noxious facility variables have the same sign in the two models, except the GASOIL power plant variable. In both models, the significant variables indicate that noxious facilities are generally associated with a wage premium. The consistency in coefficients between models is not as pronounced in the housing models. All coefficients are significant in the owners' model, but only four are in the renters'. Of those four, GASOIL and LNG have the same sign in both models, while NUCLEAR and RADCON do not. Overall, noxious facilities appear to have the effect of depressing values of owner-occupied housing but of increasing rental values.

\subsection{Estimated Implicit Prices}

Once the hedonic wage and housing expenditure equations are estimated, implicit prices for local characteristics can be derived for each study site, using Equation $7 .^{7}$ Mean values for these implicit price estimates are reported in Table V. So that the reader may judge the reliability of the estimates, we summarize the sign and significance levels for the income and housing expenditure variable coefficients for each model. We also report the mean value of the variable, and the simple correlation (across the sites) of the implicit prices for homeowners versus renters. In general, correlations between the two prices are strong and positive, typically exceeding 0.9 . However, no clear pattern emerges when comparing the magnitude of prices for owners versus renters. We discuss some of the implicit price estimates and focus on those which are derived from significant coefficients.

\subsubsection{Price, Disequilibrium, and Location Dummy Variables}

Increases in the unemployment rate have a negative impact for both owners and renters. Coastal location also has a negative value, though neither result is based on significant coefficients in both models. In contrast, an increased cost of living has negative value for owners (based on two significant coefficients) but positive for renters (based on only one significant coefficient). 


\subsubsection{Fiscal and Amenity Variables}

Per capita measures of local taxes and of local spending have negative implicit prices. For local taxes, the negative price is almost four times higher for renters than owners, while the implicit prices for local expenditures are nearly equivalent. In contrast, intergovernmental transfers have positive implicit prices for both owners and renters. Although many of the wage and income model coefficients that form the basis for fiscal variable implicit prices are statistically significant, the price estimates are unreasonably large. For example, while it may not be surprising to see negative implicit prices on local taxes or local spending (given that the latter includes redistributive spending such as welfare), we would not expect to see implicit price estimates exceeding the incremental per capita tax or spending level.

To conserve space, we examine only those implicit prices on amenities which are derived from at least one significant coefficient in both the renter and owner models. Concentrations of manufacturing employment and total suspended particulates have more negative implicit prices for renters than owners. By contrast, commuting has a more negative value for owners. This may reflect the fact that owners are less likely to live in the central city, and hence are more likely to commute longer distances. Residental location may also affect the relative implicit prices on manufacturing and total suspended particulates since air quality is typically superior in suburban as compared to urban locations. Of the climatic variables, only two (precipitation and cooling-degree-days) display significant coefficients for both owners and renters. In both cases, the implicit prices are positive and are larger for owners.

\subsubsection{Noxious Facility Variables}

Signs on implicit prices for each type of noxious facility are the same for the owner and renter samples though values differ by a factor of ten in some cases. Results are most robustst for nuclear plants, which have significant coefficients in all four models and also have similar values for owners and renters. The next strongest results are for petrochemical refineries and LNG terminals, which both have significant coefficients in three models and also have similar values. We have the least confidence in the 
results for coal-fired plants and the chemical weapons sites because they have no significant coefficients in the renters' models and only one in the owners'.

\subsection{Implicit Price Differences, Demographic Characteristics, and Mobility}

Given the differences between renters and owners shown in Table III, a relevant question is whether the observed disparity between the implicit prices for owners and renters is primarily due to demographics, mobility, or structural differences in the wage and housing regression results. To investigate this, we substitute pooled mean demographic and mobility characteristics for those of the separate owner and renter samples ${ }^{8}$ and recalculate the implicit prices using the regression parameters for the separate samples. In absolute values, implicit prices based on the pooled characteristics are generally higher for renters and lower for owners' than when calculated using renters' and owners' own characteristics. Table VI identifies the percentage change in implicit price estimates that results from substituting from either pooled demographic or pooled mobility characteristics. Compared to the separate samples, if owners and renters had identical demographic characteristics, owners' implicit prices would be on average $2.3 \%$ lower, whereas those of renters would rise by about $4.8 \%$. For the noxious facility categories considered, most of the owners' prices fell less than two percent. ${ }^{10}$ The changes due to the differential mobility of the two groups, as measured by the time period since the last move, is much smaller. When pooled mobility characteristics are substituted for owners' characteristics, implicit prices are on average virtually unchanged, and renters' prices fall by only $0.2 \%$.

Although observed differences in demographic and mobility characteristics appear to explain some of the difference between owners' and renters' implicit prices for noxious facilities, they only account for a small portion of the disparity. Thus, the differences in implicit prices may primarily reflect differences in underlying preferences and risk perception. 


\section{CONCLUDING REMARKS}

Local residents are commonly compensated when certain types of noxious facilities are sited in their cities. However, determining the appropriate level of compensation for a diverse group of residents is a difficult task. For example, previous studies have found significant differences in risk perception depending on the age, sex, and housing tenure of individuals. In this paper, we attempt to shed light on the differences in valuation of noxious facilities for homeowners versus renters using an intercity hedonic model. Though our findings do not identify any systematic pattern of differences between owners and renters, this should not be misconstrued to suggest that implicit prices are the same for the two groups. Indeed, for some variables, the implicit price estimates vary substantially across models (although they tend to move together as indicated by relatively high correlations between owners' and renters' prices). The disparities appear to be the result of different responses to community characteristics on the part of owners and renters. Differences in the mobility of the two groups account for less than one percent of the differences between owners and renters implicit valuation on average, while variations in demographic characteristics explain between two percent and five percent of the divergence. The remaining differences are due to the unique model-coefficients estimated for the two groups. Thus, future impact assessments using hedonic estimation techniques should separately consider both renters and homeowners when deriving implicit valuations of site-specific characteristics.

\section{ACKNOWLEDGEMENTS}

Data collection supported by U.S. Department of Energy, Assistant Secretary for Civilian Radioactive Waste Management, under contract W-31-109-Eng-38. 


\section{REFERENCES}

1. J.E. Kohlhase, "The Impact of Toxic Waste Sites on Housing Values," Journal of Urban Economics, 5:1-26 (1991).

2. G.C. Blomquist, M.C. Berger and J.P. Hoehn, "New Estimates of Quality of Life in Urban Areas," American Economic Review, 78, 89-107 (March 1988).

3. D.E. Clark and L.A. Nieves, "An Interregional Hedonic Analysis of Noxious Facility Impacts on Local Wages and Property Values," forthcoming in Journal of Environmental Economics and Management (1994).

4. P. Linneman, "Some Empirical Results on the Nature of the Hedonic Price Function for the Urban Housing Market," Journal of Urban Economics, 8, 47-68 (1980).

5. R.C. Mitchell, "Rationality and Irrationality in the Public's Perception of Nuclear Power," in W.R. Freudenburg and E.A. Rosa eds. Public Reactions to Nuclear Power: Are There Critical Masses? (Westview Press, Boulder, Colo., 1984).

6. S.C. Cutter, "Community Concern for Pollution: Social and Environmental Influences," Environment and Behavior, 13(1), 105-124 (1981).

7. H.L. Howe, "Predicting Public Concern Regarding Toxic Substances in the Environment," Environmental Health Perspectives, 87, 275-281 (1990).

8. H.L. Howe, "Public Concern about Chemicals in the Environment: Regional Differences Based on Threat Potential," Public Health Reports, 105(2), 186-195 (1990).

9. T.P. Boehm, "Tenure Choice and Expected Mobility: A Synthesis," Journal of Urban Economics, 10(3), 375-389 (November 1981).

10. T.P. Boehm, H.W. Herzog, and A.M. Schlottmann, "Intra-Urban Mobility, Migration, and Tenure Choíce," Review of Economics and Statistics, 73(1), 59-68 (February 1991).

11. J. Roback, "Wages, Rents, and the Quality of Life," Journal of Political Economy, 90, 1257-1278, (December 1982).

12. M.L. Cropper and A.S. Arriaga-Salinas, "Intercity Wage Differentials and the Value of Air Quality," Journal of Üban Economics, 8, 236-254 (September 1980).

13. J. Roback, "Wages, Rents, and Amenities: Differences Among Workers and Regions," Economic Inquiry, 26, 23-41 (1988).

14. J.P. Hoehn, M.C. Berger, and G.C. Blomquist, "A Hedonic Model of Interregional Wages, Rents, and Amenity Values," Journal of Regional Science, 27, 605-620 (1987).

15. U.S. Department of Commerce, Bureau of the Census, Public Use Microdata Sample B (1980). 
16. American Chamber of Commerce Researchers Association (ACCRA), Inter-City Cost of Living Indicators, Fourth Quarter Index Report (1980).

17. U.S. Department of Commerce, Bureau of the Census, County and City Data Book (U.S. Government Printing Office, Washington, D.C., 1983).

18. State Tax Handbook (Commerce Clearing House Inc., Chicago, 1977).

19. E.C. Kokkelenberg and D.R. Sockell, "Union Membership in the United States: 1973-1981," Industrial and Labor Relations Review, 38, 497-543 (July 1985).

20. NOAA, Comparative Climatic Data for the United States through 1987, National Oceanic and Atmospheric Administration; National Environmental Satellite, Data and Information Service; National Climatic Data Center, Asheville, NC (undated).

21. D.B. Garvey, S.B. Moser and D.G. Streets, In Pursuit of Clean Air: A Data Book of Problems and Strategies at the State Level, 4 Vols. (ANL/EES-TM-212. Argonne National Laboratory, Argonne, IL, 1982).

22. Argonne National Laboratory, Electric Utilities Database.

23. L.E. Rouse, "The Disposition of the Current Stockpile of Chemical Munitions and Agents," Military Law Review, 121, 17-23 (Summer 1988)

24. 40 CFR Part 300, National Priorities List for Uncontrolled Hazardous Waste Sites; Final Rule, . Federal Register, 55 (March 1990)

25. American Business Directories, U.S. Manufacturers Directory, 1988-89 edition, Omaha NE.

26. U.S. Department of Energy, Annual Report on Environmental Restoration Activity, (Government Printing Office, Washington D.C., 1991).

27. Institute of Gas Technology, Annual Statistical Report (1989).

28. H.B. Gamble and R.H. Downing, Effects of the Accident at Three Mile Island on Residential Property Values and Sales, Prepared by The Institute for Research on Land and Water Resources, Pennsylvania State University, for the U.S. Nuclear Regulatory Commission (April 1981).

29. H.B. Gamble and R.H. Downing, "The Effects of Nuclear Power Plants on Residential Property Values," Journal of Regional Science, 22, 457-478 (1982).

30. J.P. Nelson, "Three Mile Island and Residential Property Values: Empirical Analysis and Policy Implications," Land Economics, 57, 363-372 (August 1981).

31. G. Blomquist, "The Effect of Electric Utility Power Plant Location on Area Property Value," Land Economics, 50, 97-100 (February 1974). 
32. D. Harrison, Jr. and J.H. Stock, Hedonic Housing Values, Local Public Goods and Benefits of Hazardous Waste Cleanup, (Harvard University: Kennedy School of Government, Cambridge, MA, 1984).

33. V.K. Smith and W.H. Desvousges, "The Value of Avoiding a 'Lulu': Hazardous Waste Disposal Sites," Review of Economics and Statistics, LXVII, 293-299 (May 1986).

34. G. Michaels and V.K. Smith, "Market Segmentation and Valuing Amenities with Hedonic Models: The Case of Hazardous Waste Sites, "Journal of Urban Economics, 28, 223-242 (1990).

35. G.H. McClelland, W.D. Schulze, and B. Hurd, "The Effect of Risk Beliefs on Property Values: A Case Study of a Hazardous Waste Site," Risk Analysis, 10, 485-497 (December 1990).

36. R.K. Hageman, "Nuclear Waste Disposal: Potential Property Value Impacts," Natural Resources Journal, 21, 789-810 (October 1981).

37. L.A. Nieves, J.J. Himmelberger, S.J. Ratick, and A.L. White, "Negotiated Compensation for SolidWaste Disposal Facility Siting: An Analysis of the Wisconsin Experience," Risk Analysis, 12, 505-511 (December 1992).

38. G.L. Hunt, "Equilibrium and Disequilibrium in Migration Modelling," Regional Studies, 27(4), 341-349 (1993).

39. F.J. Harrigan and P.G. McGregor, "Equilibrium and Disequilibrium Perspectives on Regional Labor Migration," Journal of Regional Science, 33(1), 49-67 (1993).

41. J. Schachter and P.G. Althaus, "The Assumption of Equilibrium in Models of Migration," Journal of Regional Science, 33(1), 85-88 (1993).

40. P.E. Graves and P.R. Mueser, " The Role of Equilibrium and Disequilibrium in Modelling Regional Growth and Decline: A Critical Reassessment," Journal of Regional Science, 33(1), $69-84$ (1993).

42. A.W. Evans "Interregional Equilibrium : A Transatlantic View," Journal of Regional Science, 33(1), 89-97, (February 1993).

43. M.J. Greenwood, G.L. Hunt, D.S. Rickman, and G.I. Treyz, "Migration, Regional Equilibrium, and the Estimation of Compensating Differentials, "American Economic Review, 81, 1382-1390 (1991).

44. H.W. Herzog and A.M. Schlottmann, "Valuing Amenities and Disamenities of Urban Scale: Can Bigger Be Better?" Journal of Regional Science, 33, 145-165 (1993). 
Table I. Number of Facilities by Facility Type and Census Region

\begin{tabular}{|c|c|c|c|c|c|c|c|c|c|}
\hline & \multicolumn{8}{|c|}{ Type of Facility } & \multirow[b]{2}{*}{ Total } \\
\hline Region (sites) & Nuclear & Coal & Gasoil & Chmdmil & Hazwst & Refine & Radcon & LNG & \\
\hline $\begin{array}{l}\text { New England } \\
(5)\end{array}$ & 2 & 0 & 6 & 0 & 4 & 0 & 0 & 1 & 13 \\
\hline $\begin{array}{l}\text { Mid Atlantic } \\
\text { (15) }\end{array}$ & 5 & 10 & 8 & 0 & 43 & 5 & 4 & 3 & 78 \\
\hline $\begin{array}{l}\text { S Atlantic } \\
\text { (17) }\end{array}$ & 5 & 7 & 9 & 1 & 9 & 1 & 0 & 3 & 35 \\
\hline $\begin{array}{l}\text { EN Central } \\
\text { (8) }\end{array}$ & 1 & 11 & 4 & 1 & 8 & 2 & 0 & 0 & 27 \\
\hline $\begin{array}{l}\text { ES Central } \\
\text { (4) }\end{array}$ & 1 & 2 & 0 & 2 & 2 & 0 & 0 & 2 & 9 \\
\hline $\begin{array}{l}\text { WN Central } \\
(8)\end{array}$ & 0 & 4 & 12 & 0 & 7 & 4 & 2 & 1 & 30 \\
\hline $\begin{array}{l}\text { WS Central } \\
(6)\end{array}$ & 1 & 2 & 6 & 0 & 7 & 15 & 0 & 0 & 31 \\
\hline $\begin{array}{l}\text { Mountain } \\
\text { (4) }\end{array}$ & 0 & 3 & 4 & 2 & 3 & 2 & 0 & 0 & 14 \\
\hline $\begin{array}{l}\text { Pacific } \\
(9)\end{array}$ & 6 & 0 & 4 & 0 & 10 & 4 & 0 & 1 & 25 \\
\hline TOTAL (76) & 21 & 39 & 53 & 6 & 93 & 33 & 6 & 11 & 262 \\
\hline
\end{tabular}


Table II. Variables and Data Sources

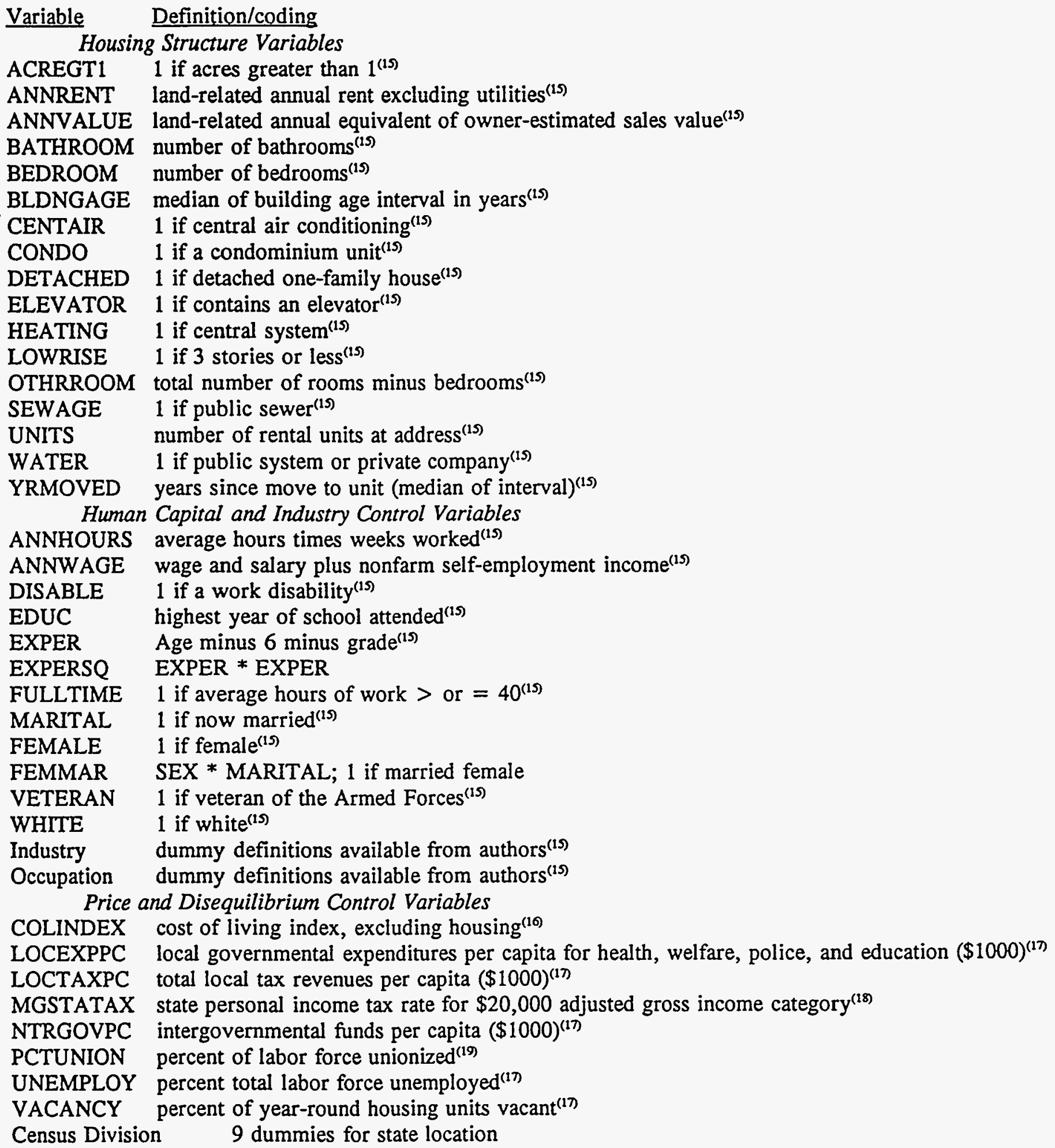


Table II. Variables and Data Sources (Continued)

Variable Definition/coding

(Dis)Amenity Variables

AVGWIND average wind speed in miles per hour ${ }^{(20)}$

CNTRLCTY 1 if central city of SMSA ${ }^{(1)}$

COAST 1 if sea coast location

COOLDAYS total cooling-degree-days ${ }^{(1)}$

HEATDAYS total heating-degree-days ${ }^{(1)}$

MEANTRAV mean travel time to work in minutes ${ }^{(1)}$

PCTMFG percent of employment in manufacturing ${ }^{(17)}$

PCTSUN realized percent of potential sunlight ${ }^{(00)}$

POPDENS population per square mile ${ }^{(1)}$

PRECIP annual inches of precipitation ${ }^{(20)}$

RURAL $\quad 1$ if outside SMSA ${ }^{(1)}$

TEMPDIFF annual range of daily mean temperatures ${ }^{\circ} \mathrm{F}{ }^{(1)}$

TSP annual average total suspended particulates ${ }^{(21)}$

VCRIMES violent crimes per capita ${ }^{(1)}$

Facility Variables (density per $1000 \mathrm{mi}^{2}$ )

NFDNSNUP nuclear power plant ${ }^{(2)}$

NFDNSCOP coal-fired power plant ${ }^{(2)}$

NFDNSGOP gas- and oil-fired power plant ${ }^{(2)}$

NFDNSCHM chemical weapons storage site ${ }^{(2)}$

NFDNSHWS hazardous waste site ${ }^{(24)}$

NFDNSPCR petrochemical refinery(2)

NFDNSRAC radioactive contaminated site ${ }^{(20)}$

NFDNSLNG liquefied natural gas storage site ${ }^{(27)}$ 
Table III. Mean Values of Demographic Variables for Owners and Renters"

\begin{tabular}{|c|c|c|c|c|}
\hline \multirow[t]{2}{*}{ Demographic Variables } & \multicolumn{2}{|c|}{ Owners } & \multicolumn{2}{|c|}{ Renters } \\
\hline & Mean & S.D. & Mean & S.D. \\
\hline Educ & 14.76 & 2.87 & 14.75 & 2.85 \\
\hline Exper & 19.04 & 14.01 & 14.33 & 13.58 \\
\hline Female & 0.45 & - & 0.46 & - \\
\hline Married & 0.68 & - & 0.47 & - \\
\hline Femmar & 0.27 & - & 0.18 & - \\
\hline White & 0.85 & - & 0.80 & - \\
\hline Fulltime & 0.76 & - & 0.77 & - \\
\hline Disabled & 0.04 & - & 0.04 & - \\
\hline Veteran & 0.24 & - & 0.18 & - \\
\hline Annhours & 1871.60 & 670.20 & 1855.25 & 656.05 \\
\hline Cntrlety & 0.40 & - & 0.46 & - \\
\hline Rural & 0.20 & - & 0.17 & - \\
\hline Yrmoved & 13.68 & 13.71 & 3.98 & 6.23 \\
\hline
\end{tabular}

- Standard deviations are irrelevant for qualitative variables, and thus are not reported. 
Table IV. Regression Coefficients for Owner and Renter Income and Housing Models

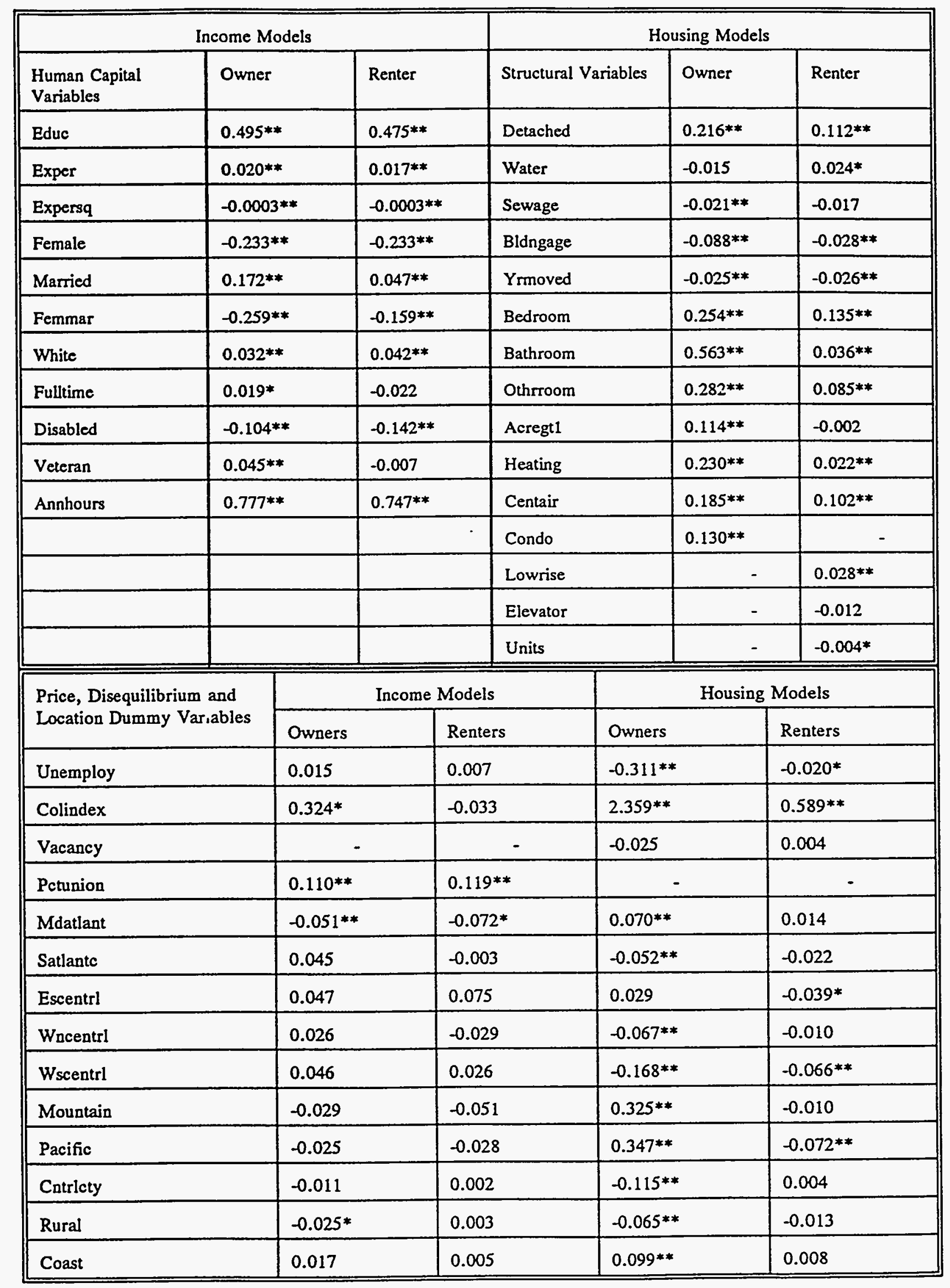


Table IV. Regression Coefficients for Owner and Renter Income and Housing Models (Continued)

\begin{tabular}{|c|c|c|c|c|}
\hline \multirow{2}{*}{$\begin{array}{l}\text { Fiscal and Amenity } \\
\text { Variables }\end{array}$} & \multicolumn{2}{|c|}{ Income Models } & \multicolumn{2}{|c|}{ Housing Models } \\
\hline & Owners & Renters & Owners & Renters \\
\hline Mgstatax & -0.0005 & -0.010 & -0.00006 & -0.006 \\
\hline Loctaxpc & -0.0003 & 0.036 & $-0.064^{* *}$ & $0.059 * *$ \\
\hline Ntrgovpc & -0.041 & -0.028 & $-0.049 * *$ & $-0.034^{*}$ \\
\hline Locexppc & $0.123^{* *}$ & 0.112 & $0.110^{* *}$ & $-0.057^{*}$ \\
\hline Precip & $-0.061 * *$ & -0.041 & $-0.033^{*}$ & $-0.061^{* *}$ \\
\hline Tempdiff & -0.010 & 0.055 & $-0.538 * *$ & -0.011 \\
\hline Heatdays & 0.026 & -0.029 & $0.306^{* *}$ & -0.030 \\
\hline Cooldays & -0.004 & -0.012 & $0.081^{* *}$ & $-0.031^{* *}$ \\
\hline Avgwind & -0.004 & 0.037 & $0.414^{* *}$ & 0.027 \\
\hline Pctsun & 0.046 & 0.032 & $0.154^{* *}$ & -0.017 \\
\hline Popdens & -0.009 & -0.019 & $0.023^{* *}$ & 0.003 \\
\hline Commute & 0.015 & 0.007 & $-0.081^{* *}$ & $0.053^{* *}$ \\
\hline Vcrime & $0.041^{* *}$ & 0.027 & $-0.021 * *$ & 0.006 \\
\hline Pctmanuf & 0.024 & $0.060^{*}$ & $-0.033 * *$ & -0.007 \\
\hline TSP & $0.043^{*}$ & $0.076^{*}$ & $-0.032^{*}$ & $-0.029^{* *}$ \\
\hline \multirow[t]{2}{*}{ Noxious Facility Variables } & \multicolumn{2}{|c|}{ Income Models } & \multicolumn{2}{|c|}{ Housing Models } \\
\hline & Owners & Renters & Owners & Renters \\
\hline Nuclear & $0.007^{* *}$ & $0.011^{*}$ & $-0.005^{* *}$ & $0.005^{* *}$ \\
\hline Coal & 0.003 & 0.0001 & $-0.008 * *$ & -0.002 \\
\hline Gasoil & 0.001 & -0.00002 & $-0.008^{* *}$ & $-0.005^{* *}$ \\
\hline Refinery & $0.015^{* *}$ & $0.017^{* *}$ & $-0.016^{* *}$ & 0.002 \\
\hline Hazwaste & -0.003 & -0.004 & $0.015^{* *}$ & 0.001 \\
\hline LNG & 0.004 & $0.010^{*}$ & $0.005^{* *}$ & $0.007^{* *}$ \\
\hline Radcon & 0.001 & 0.009 & $-0.008^{* *}$ & $0.007 * *$ \\
\hline Chemdmil & -0.005 & -0.007 & $-0.026^{* *}$ & 0.002 \\
\hline INTERCEPT & 0.304 & 2.294 & $-6.106^{* *}$ & $5.815^{* *}$ \\
\hline F Stat & 746.763 & 150.268 & 1288.730 & 81.244 \\
\hline Adj $R^{2}$ & 0.6644 & 0.5790 & 0.5789 & 0.2543 \\
\hline Obs. & 23735 & 6838 & 45899 & 11999 \\
\hline
\end{tabular}

** $<0.01$ level of significance

$*<0.05$ level of significance 


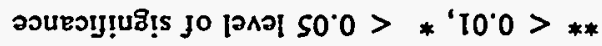

\begin{tabular}{|c|c|c|c|c|c|c|}
\hline$* * 666^{\circ}$ & $* *+1 *+$ & $00^{\circ} 0 L^{-}$ & $* *+1+$ & $\bar{c} I^{\cdot} 6 \bar{c}^{-}$ & $19^{\circ} 0$ & !w bs 000I/DNT \\
\hline$* * 2+6^{\circ}$ & $* *+1+$ & $\bar{\tau} \iota \overline{c t}$ & $* *-1+$ & $69^{\circ} 0 I^{-}$ & $0 \vec{c} 0$ & 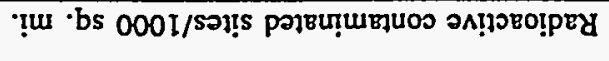 \\
\hline$* * 686^{\circ}$ & $+1 * *+$ & St'SEL- & $* *-1 * *+$ & $88^{\circ} \angle 9 C^{-}$ & $89^{\circ} 0$ & 'tul bs 000I/soịautjas [Botuayoorlad \\
\hline$* 286^{\circ}$ & $* *+1+$ & $\mapsto I^{\circ}$ & $* *+1-$ & $8 t^{\circ} 85$ & $80 \cdot \tau$ & 'tu ·bs 000I/rJsem snoprezeH \\
\hline$* * \circ 06^{\circ}$ & $+1-$ & $L L \cdot \varepsilon \bar{C}$ & $* *-1-$ & $28^{\circ} s t$ & $80 \%$ & 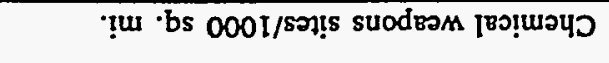 \\
\hline$* * T \angle 6^{\circ}$ & $* *-1-$ & $88^{\circ} \bar{c}^{-}$ & $* *-1+$ & It'SE- & $09^{\circ} I$ & ?u ·bs 000I/sque[d pary-l!o/seD \\
\hline ** $966^{\circ}$ & $-1+$ & $L L^{*} I^{-}$ & $* *-1+$ & $E I^{\circ} S t$ & $85^{\circ} 0$ & 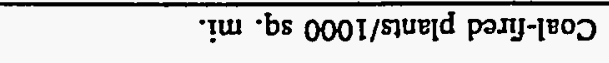 \\
\hline$* * \$ 66^{\circ}$ & $* *+/ *+$ & $60^{\circ} \varepsilon 8 I^{-}$ & $* *-1 * *+$ & $89^{\circ} \mathrm{Zt} I^{-}$ & $\$ 20$ & 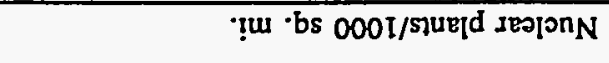 \\
\hline$* * 10 L^{\circ}-$ & $+1+$ & $8 \varepsilon^{\circ} 6 \varepsilon^{-}$ & $* *+1-$ & $99^{\circ} \approx L$ & $I I^{\circ} 6$ & pəods pu!n ว8ียวคท \\
\hline$* * \$ 96^{\circ}$ & $* *-1 / *+$ & $\varepsilon \tau^{\cdot} \varepsilon I^{-}$ & $*-1 *+$ & IE' $6^{-}$ & $\varepsilon 8^{\circ} \$ 9$ & 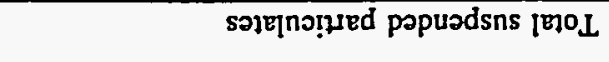 \\
\hline$* * 995^{\circ}$ & $-1-$ & $288^{\circ}$ & $* *+1+$ & $s t^{*} 0$ & $85^{\circ} 25 t$ & 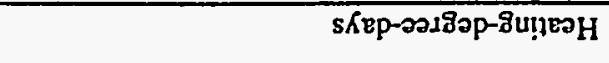 \\
\hline$* * 9 \angle 6^{\circ}$ & $* *-1-$ & $9 S^{\circ} I$ & $* *+1-$ & $\varpi \tau$ & $\nabla \varepsilon^{\circ} \triangleright \varepsilon I$ & 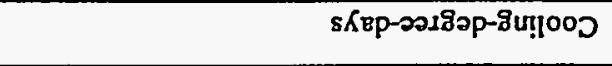 \\
\hline$* * 016^{\circ}$ & $-1+$ & $29^{\circ}+I^{-}$ & $* *-1-$ & $6 I^{\circ} 6 I^{-}$ & $\varepsilon 6^{\circ} 0 t$ & 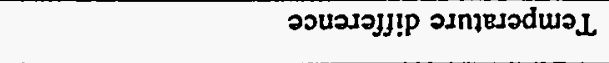 \\
\hline$* \approx \varepsilon 66^{\circ}$ & $* *-1-$ & $9 S \div$ CI & $*-1 * *$ & $\$ 8^{\circ} 0 \tau$ & $5 I^{\circ} 8 \varepsilon$ & uo!je!! \\
\hline ** 9ع9. & $-1+$ & $09^{\circ} \mathrm{s}^{-}$ & $* *+1+$ & II's- & $65^{\circ} 85$ & sKep Kuuns juosjod \\
\hline$* * 686^{\circ}$ & $+1+$ & $10^{\circ} I^{-}$ & $* *-/ * *+$ & S8: I- & $0 \varepsilon \cdot 0 S t$ & uo!̣elndod $000^{\prime} 00$ I jad sauryo juग0! $\Lambda$ \\
\hline$* * 0 \varepsilon 8^{*}$ & $* *+1+$ & $s c \cdot \tau-$ & $* *-1+$ & oz'EI- & $10^{\circ} \varepsilon \bar{C}$ & 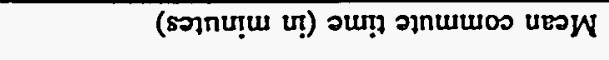 \\
\hline$* * 6 \angle 6^{\circ}$ & $-1 *+$ & $9 I^{\circ} 0 \varepsilon^{-}$ & $* *-1+$ & $66^{\circ} \mathrm{SI}^{-}$ & $\forall 8^{\circ} \tau \tau$ & 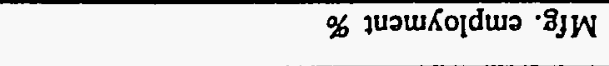 \\
\hline$* * \$ 66^{\circ}$ & $+1-$ & $9+\tau$ & $* *+1-$ & $08^{\circ} I$ & SI088 & Kı!suəp uo!jęndod \\
\hline$* * 256^{*}$ & $*-1-$ & Iナ・EIZI & $* *-1-$ & ๑と.9ع8I & $\$ Z^{\circ} 0$ & 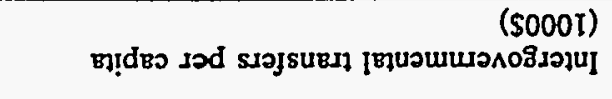 \\
\hline$* * \$ \$ 6^{\circ}$ & $*-1+$ & $09^{\circ} 0 E \angle Z-$ & $* *+1 * *+$ & $0 L^{\circ} 9 L 6 Z^{-}$ & $\nabla \nabla^{\circ} 0$ & 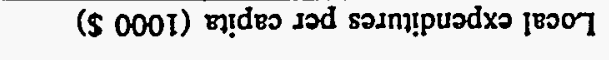 \\
\hline$* * 6 \varepsilon L^{\circ}$ & $* *+1+$ & $59^{\circ}+t I^{-}$ & $* *-1$ & $8 \varepsilon^{\circ} 85 \varepsilon^{-}$ & $62 \% 0$ & (\$ 000l) BI!des Jod XE] [EOOT \\
\hline$* * 186^{\circ}$ & $-1-$ & 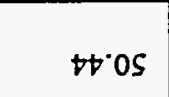 & $-1-$ & $90^{\circ} \varepsilon$ & $08^{\circ} \mathrm{I}$ & 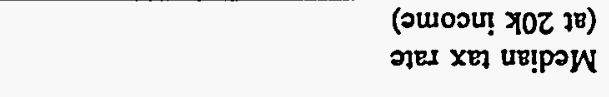 \\
\hline$\angle 80^{\circ}-$ & $+1+$ & $6 t^{\circ} 0^{-}$ & $* *+1+$ & $\angle I^{\circ} O^{-}$ & $68^{\circ} \tau \varepsilon$ & 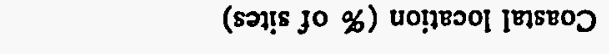 \\
\hline$\angle 60^{\circ}-$ & $* *+1-$ & $6 \tau^{\circ} S$ & $* *+/ *+$ & $L L \tau^{-}$ & $\angle Z^{\prime} I O I$ & 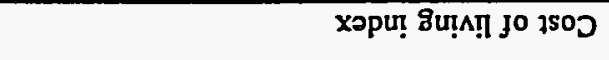 \\
\hline$* * 8+8^{\circ}$ & $*-1+$ & $6 \mathrm{CZI}^{\circ}$ & $* *-1+$ & ZL:20I- & $\angle 8 \cdot 9$ & 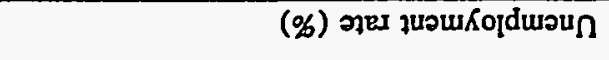 \\
\hline 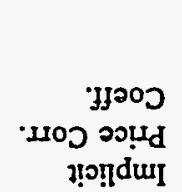 & 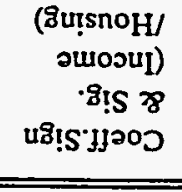 & 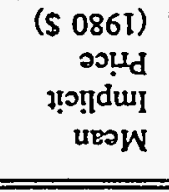 & 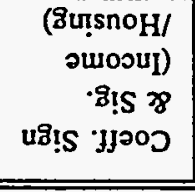 & 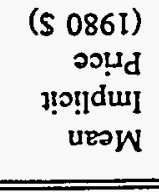 & $\begin{array}{l}\text { วกje } \Lambda \\
\text { uEכ } W\end{array}$ & Р१षप̣ष $\Lambda$ \\
\hline faumo & \multicolumn{2}{|c|}{ srajuə̃ } & \multicolumn{2}{|c|}{ staumo } & & \\
\hline
\end{tabular}


Table VI. Sensitivity of Implicit Prices to Demographic Characteristics and Mobility Differences

\begin{tabular}{|c|c|c|c|c|c|c|}
\hline \multirow{3}{*}{ Variable } & \multicolumn{3}{|c|}{ Implicit Price Estimates } & \multicolumn{3}{|c|}{ Implicit Price Estimates } \\
\hline & $\begin{array}{l}\text { Owners } \\
\text { Sample }\end{array}$ & $\begin{array}{c}\text { w /Pooled } \\
\text { Demog. } \\
\text { Chars. }\end{array}$ & $\begin{array}{l}\text { w /Pooled } \\
\text { Mobility } \\
\text { Chars. }\end{array}$ & $\begin{array}{l}\text { Renters } \\
\text { Sample }\end{array}$ & $\begin{array}{c}\text { w /Pooled } \\
\text { Demog. } \\
\text { Chars. }\end{array}$ & $\begin{array}{l}\text { w /Pooled } \\
\text { Mobility } \\
\text { Chars. }\end{array}$ \\
\hline & $\begin{array}{l}\text { Mean } \\
(1980 \$)\end{array}$ & $\begin{array}{c}\% \text { change } \\
\text { (avg.=- } \\
2.3 \%)\end{array}$ & $\begin{array}{c}\% \text { change } \\
\text { (avg. = - } \\
0 \%)\end{array}$ & $\begin{array}{l}\text { Mean } \\
(1980 \$)\end{array}$ & $\begin{array}{l}\% \text { change } \\
(\text { avg. }=4.8)\end{array}$ & $\begin{array}{c}\text { \% change } \\
\text { (avg. =- } \\
0.2 \text { ) }\end{array}$ \\
\hline Unemployment rate (\%) & -102.72 & -0.4 & 0.3 & -12.29 & 3.6 & -0.3 \\
\hline Cost of living index & -2.77 & -18.4 & -5.7 & 5.29 & 2.6 & -1.5 \\
\hline Coastal location ( $\%$ of sites) & -0.17 & -11.8 & 0.0 & -0.49 & 4.1 & 0.0 \\
\hline $\begin{array}{l}\text { Median tax rate } \\
\text { (at 20k income) }\end{array}$ & 3.06 & -1.3 & 0.0 & -50.44 & 3.8 & 0.1 \\
\hline Local tax per capita (1000 \$) & -358.38 & -0.1 & 0.4 & -1444.65 & 5.1 & 0.3 \\
\hline $\begin{array}{l}\text { Local expenditures per capita } \\
(1000 \mathrm{~S})\end{array}$ & -2976.70 & -1.6 & -0.1 & -2730.60 & 4.5 & -0.7 \\
\hline $\begin{array}{l}\text { Intergovernmental transfers per } \\
\text { capita }(1000 \mathrm{~S})\end{array}$ & 1836.34 & -1.7 & -0.1 & 1213.41 & 4.5 & 0.2 \\
\hline Population density & 1.80 & -1.1 & 0.0 & 2.46 & 5.7 & -0.4 \\
\hline Mfg. employment $\%$ & -15.99 & -1.3 & 0.1 & -30.16 & 4.1 & -0.0 \\
\hline Mean commute time (in minutes) & -13.20 & -0.9 & 0.2 & -2.25 & 6.2 & 1.3 \\
\hline $\begin{array}{l}\text { Violent crimes per } 100,000 \\
\text { population }\end{array}$ & -1.85 & -1.6 & 0.0 & -1.01 & 5.0 & 1.0 \\
\hline Percent sunny days & -5.11 & -2.5 & -0.2 & -5.60 & 4.3 & -0.2 \\
\hline Precipitation & 20.84 & -1.7 & -0.1 & 12.56 & 4.8 & 0.2 \\
\hline Temperature difference & -19.19 & 0.2 & 0.4 & -14.62 & 4.0 & 0.0 \\
\hline Cooling-degree-days & 2.44 & -0.4 & 0.4 & 1.56 & 4.5 & 0.6 \\
\hline Heating-degree-days & 0.45 & 4.4 & 2.2 & 0.82 & 3.7 & 0.0 \\
\hline Total suspended particulates & -9.31 & -1.3 & 0.0 & -13.23 & 4.4 & -0.8 \\
\hline Average wind speed & 72.66 & -0.1 & 0.3 & -39.38 & 12.2 & 0.1 \\
\hline Nuclear plants/1000 $\mathrm{mi}^{2}$ & -142.68 & -1.5 & 0.0 & -183.09 & 5.4 & 0.1 \\
\hline Coal-fired plants/1000 $\mathrm{mi}^{2}$ & -45.13 & -1.1 & 0.1 & -1.77 & 3.4 & -1.7 \\
\hline Gas/oil-fired plants/1000 $\mathrm{mi}^{2}$ & -35.41 & -0.5 & 0.2 & -2.88 & -0.7 & -4.9 \\
\hline Chemical weapons sites $/ 1000 \mathrm{mi}_{2}$ & 45.82 & -10.4 & -0.9 & 223.77 & 8.8 & -0.0 \\
\hline Hazardous waste/1000 $\mathrm{mi}^{2}$ & 58.48 & -1.0 & 0.1 & 42.14 & 5.1 & -0.0 \\
\hline Petrochemical refineries $/ 1000 \mathrm{mi}^{2}$ & -267.88 & -1.4 & 0.0 & -235.45 & 4.7 & 0.0 \\
\hline $\begin{array}{l}\text { Radioactive contaminated } \\
\text { sites } / 1000 \mathrm{mi}^{2}\end{array}$ & -10.64 & -0.6 & 0.2 & -42.72 & 6.5 & -0.1 \\
\hline $\mathrm{LNG} / 1000 \mathrm{mi}^{2}$ & -29.12 & -1.9 & -0.1 & -70.00 & 5.1 & 0.1 \\
\hline
\end{tabular}


1. For example, Gamble and Downing ${ }^{(28,29)}$ and Nelson ${ }^{(30)}$ examine nuclear power plants; Blomquist ${ }^{(31)}$ examines coal-fired power plants; and Harrison and Stock, ${ }^{(32)}$ Smith and Desvousges, ${ }^{33}$ Michaels and Smith, ${ }^{(34)}$ and McClelland, Schulze, and Hurd ${ }^{(3)}$ investigate hazardous waste facilities.

2. Blomquist, Berger and Hoehn ${ }^{(2)}$ develop a quality of life index which includes effects of landfill waste sites, Superfund sites, and treatment, storage and disposal sites for hazardous wastes. Clark and Nieves ${ }^{(3)}$ use the intercity model to develop implicit prices for home owners for eight different types of noxious facilities. These same facilities are investigated in the current study.

3. A more general model, which incorporates the effect of compensation for damages, similar to that developed by Hageman ${ }^{(3)}$ in an intracity model, is not considered in this paper. The reason is that this model is applied to 1979 data. While the possibility of compensation for damages existed in 1979, the probability was actually quite low. Over the last decade, the likelihood of communitywide compensation increased. For example, Nieves, Himmelberger, Ratick and White ${ }^{(37)}$ examine negotiated settlements between Wisconsin communities and waste disposal facilities. These settlements exist as a result of a 1981 Wisconsin law which establishes a process for negotiating compensation when siting waste disposal sites in the state.

4. The influence of the disamenity on both wages and land rents can only be predicted if the unit cost function does not shift with the disamenity level (i.e., the disamenty is neither productivity enhancing nor does it reduce productivity as in the example above). In that case, increases in the disamenity decrease rents and increase the wage. If the disamenity increases productivity, then wages rise unambiguously but the impact on rents depends on the relative strengths of the shifts in the unit cost and indirect utility functions.

5. The assumption of regional equilibrium has been called into question recently. See recent papers by Hunt, ${ }^{(3)}$ Harrigan and McGregor, ${ }^{(39)}$ Graves and Mueser, ${ }^{(40)}$ Schachter and Althaus, ${ }^{(41)}$ and Evans ${ }^{(42)}$ for example. Furthermore, Greenwood, Hunt, Rickman and Treyz ${ }^{(43)}$ and Herzog and Schlottmann ${ }^{(44)}$ show that willingness to pay estimates can be derived as the wage premium required to prevent outmigration. Since we are concerned with both the wage and property value effects of noxious facilities, this approach is not used. Instead, we control for regional disequilibrium by including regional dummy variables, and specific control variables such as the vacancy rate in the housing models, and the unemployment rate for 
the income models. However, it is recognized that the implicit prices derived may differ from the true willingness to pay to the extent that disequilibrium remains uncontrolled.

6. The hazardous waste category is mainly composed of Superfund sites. In addition, this category includes two operating commercial low-level radioactive waste disposal facilities.

7. For owners, we follow Roback ${ }^{(11)}$ and assume that $19.6 \%$ of housing expenditure is devoted to land. However, since Roback's estimate is derived from a sample of owners, and since we were unable to identify a corresponding value estimated from a sample of rental properties, we tested the sensitivity of the implicit price estimates for renters to this assumption of the land share component. Increasing the land share by $40 \%$ to $27.4 \%$ (i.e., $0.274=0.196 * 1.4$ ) typically changed implicit price estimates by less than $1 \%$. The notable exceptions are coal-fired plants whose implicit prices rose by $10 \%$ on average, and gas- and oil-fired plants, whose prices rose $42 \%$ on average. Note that both of these types of power plants had very low values for implicit prices, ranging from $1-2 \%$ of the implicit price for nuclear plants.

8. The mean of the pooled renter and owner sample of workers for each site was used to derive the demographic values which were then substituted into the respective wage equations.

9. In no case did an implicit price change sign as a result of substituting pooled demographic and/or mobility characteristics for individual levels. Thus, for example when implicit prices for renters' rise in absolute value terms, this implies that negative values become more negative and positive values more positive. Furthermore, when owners' implicit prices are shown to decrease, this means that negative values become less negative, and positive prices less positive.

10. An exception is for chemical weapons storage facilities whose implicit price fell over $10 \%$ when owners' were assigned pooled sociodemographic characteristics. Note however that this price is unexpectedly positive, resulting from a positive, albeit insignificant coefficient in the hedonic wage regression. Thus, since the positive wage component of the implicit price dominated the negative land rent component, the change in the demographic characteristics which leads to lower predicted wages for owners, has a relatively strong negative effect on their implicit price. 